Indian J Anim Health (2022)

DOI: https://doi.org/10.36062/ijah.2022.07821

\title{
Seroprevalence of Neospora caninum infection among cattle in Trissur district of Kerala
}

\author{
H. S. Gagana ${ }^{1 *}$, K. Justin Davis ${ }^{1}$, K. Vinod $\operatorname{Kumar}^{1}$ and K. Vijayakumar $^{1}$ \\ ${ }^{1}$ Department of Veterinary Epidemiology and Preventive Medicine, College of Veterinary and Animal \\ Sciences, Mannuthy - 680 651, Thrissur, Kerala, India
}

\begin{abstract}
A study was conducted to determine the presence of anti-Neospora caninum antibodies among cattle in the Thrissur district of Kerala. A total of 92 animals were screened through indirect ELISA using Neospora caninum antibody test kit. Antibodies against Neospora caninum was found to be present in $64.13 \%$ of the animals tested. The presence of antibodies is indicative of either pre-infection or prenatal infection. The high prevalence of antibodies in cattle of Thrissur has to be viewed seriously and warrants a detailed study.
\end{abstract}

Key words: ELISA, Neospora caninum, Seroprevalence

\section{Highlights}

- Antibodies against $N$. caninum infection was determined successfully by ELISA.

- The sample study revealed a high seroprevalence of $N$. caninum infection in cattle in Thrissur district of Kerala.

- The diagnostic accuracy testing of the ELISA kit revealed satisfactory comprehensions with high positive predictive value and negative predictive value.

- The likelihood ratios also suggested the test as highly efficient in terms of the probability of the outcome.

Neospora caninum is a protozoan parasite seen in dogs and other domesticated animals including cattle. The organism spreads from infected dogs to cattle mainly by consuming fodder contaminated with dog faeces (Gao and Wang, 2019). Vertical transmission through placenta was also found to be the major route for spreading of infection among cattle herd apart from soiled feedlot (Neverauskas et al., 2015). In cattle, the infection has been associated with abortion, increased culling and reduced milk yield. In addition, Neospora has been reported in numerous cases of stillbirth and neonatal mortality, and the same is likely to contribute to early foetal death and resorption thereby reducing the value of female breeding cattle (Antony and Williamson, 2001).

A total of 92 cattle were selected randomly from different farms located in and around
Thrissur district of Kerala. Blood samples were collected from these animals and sera were separated after centrifugation at $1500 \times \mathrm{g}$ for 10 minutes and were stored at $-20^{\circ} \mathrm{C}$ until laboratory testing. Anti-Neospora IgGantibodies of the samples were detected using a commercially available ELISA kit (IDEXX, USA). The kit was used according to the manufacturer's instructions, and the cut-off values were applied accordingly. The test had been widely used and was quoted as a "reference standard" by Nasir et al. (2012). The seroprevalence of antibody was determined by calculating sample to positive ratio $(\mathrm{S} / \mathrm{P}>0.5=$ positive).

Epidemiological parameters such as apparent prevalence, true prevalence, diagnostic accuracy with positive predictive value, negative predictive value, likelihood ratio 
for positive and negative tests ratio were calculated using standard formulas.

The ELISA test estimated 59 samples positive for the presence of antibodies out of 92 samples tested for Neospora caninum in the bovine serum. Apparent prevalence of $\mathrm{IgG}$ antibodies to $N$. caninum was found to be $64.13 \%(\mathrm{n}=59 /$ 92) $(\mathrm{CI}=53.95-73.18)$ with true prevalence $63.3 \% \quad(\mathrm{CI}=52.57-72.8) \quad$ (Table 1$)$. The seroprevalence of $N$. caninum was reported as $0.7-97.2 \%$ in cattle worldwide (Dubey and Schares, 2011). Himachala et al. (2020) reported $18 \%$ seroprevalence in Kerala (India) by Fluorescent Antibody Test among cattle with recent history of abortions. It was also reported that 5.26 per cent of the positive samples were collected from organized farms.

The predictive value of the positive test and negative test with the likelihood ratios are mentioned in Table 2. High predictive values for the positive and negative tests with a positive likelihood ratio value of more than 10 and a negative likelihood ratio of less than 0.10 establishes the reliability of the test conducted.

The presence of antibodies against Neospora sp. may indicate either previous infection or prenatal infection, and it is possible for a herd to have high seroprevalence without any abortions occurring in the herd. Once infected, the infection was found to prevail for life and the animal could transmit the disease to young ones vertically causing huge economic loss (Antony and Williamson, 2001). The high occurrence of antibodies in the cattle population of Thrissur, revealed in this study, has to be taken seriously and warrants a detailed study. Since there are no available vaccines or definitive treatments for Neospora caninum infection in cattle, prevention

Table 1. Apparent prevalence and true prevalence of $N$. caninum infection

\begin{tabular}{lccc}
\hline Parameters & Formulas & Value (\%) & Confidence interval \\
\hline $\begin{array}{l}\text { Apparent } \\
\text { prevalence }\end{array}$ & $\begin{array}{c}\text { apparent prevalence }(\%) \\
\text { total test positive }\end{array} \times 100$ & 64.13 & $53.95-73.18$ \\
\hline $\begin{array}{l}\text { total sampale } \\
\text { prue }\end{array}$ & $\begin{array}{l}\text { true prevalence }(\%) \\
\text { apparet prevalence }+ \text { specificity }-1\end{array} \times 100$ & 63.30 & $52.57-72.80$ \\
\hline
\end{tabular}

Total sample screened: 92, Total sample positive: 59

Table 2. Predictive values (\%) and likelihood ratios of ELISA

\begin{tabular}{lcc}
\hline Parameters & Formulas & Values \\
\hline $\begin{array}{l}\text { Positive } \\
\text { predictive } \\
\text { value }\end{array}$ & sensitivity $\times$ prevalence & $97 \%$ \\
\hline $\begin{array}{l}\text { Negative } \\
\text { predictive }\end{array}$ & {$[($ sensitivity $\times$ prevalence $)+(1-$ specificity $)(1-$ prevalence $)]$} & \\
value & sensitivity $\times(1-$ prevalence $)$ & $98 \%$ \\
\hline $\begin{array}{l}\text { Positive } \\
\text { likelihood } \\
\text { ratio }\end{array}$ & $\frac{\text { sensitivity }}{1-\text { sensitivity }}$ & \\
\hline $\begin{array}{l}\text { Negative } \\
\text { likelihood } \\
\text { ratio }\end{array}$ & prevalence $]+[$ specificity $\times(1-$ prevalence $)]$ & 24.75 \\
& sensitivity & $(>1)$ \\
\hline
\end{tabular}


is the best method to avoid the disease.

For the control of infections, the role of dogs in horizontal transmission should be studied. Abortions in the herd should not be ignored, and animals found positive should be culled and removed from breeding.

Neospora infection is a potential threat to farm animals in terms of production and breeding and hence should be seriously reviewed. The study revealed a high prevalence of antibodies against Neospora among cattle in the Thrissur district. Since there are reports suggesting seroprevalence in organized farms, it is crucial to monitor abortions in the herd.

\section{REFERENCES}

Antony A and Williamson NB, 2001. Recent advances in understanding the epidemiology of Neospora caninum in cattle. N Z Vet J, 49(2): 42-47, doi: 10.1080/00480169.2001.36201

Dubey JP and Schares G, 2011. Neosporosis in animalsthe last five years. Vet Parasitol, 180(1-2): 90108, doi: 10.1016/j.vetpar.2011.05.031

Gao X and Wang H, 2019. Seroprevalence and risk factors for Neospora caninum infection in dogs in rural northeastern mainland China. Parasite, 26, doi: 10.1051/parasite/2019034

Himachala K, Devada K, Bindu L, Lucy S, Asha R et al., 2020. Seroprevalence of Neospora caninum among aborted cattle in central Kerala, India. J
Conflict of interest: Authors have no conflict of interest in this study.

Author's contribution: KV, KJD: Study conception and design; HSG, KJD: Data collection; KJD, KVK: Analysis and interpretation of results; HSG, KJD: Drafting of manuscript preparation.

\section{ACKNOWLEDGMENTS}

The authors thank the Dean, College of Veterinary and Animal Sciences, Mannuthy, Kerala Veterinary and Animal Sciences University, for the facilities provided.

Indian Vet Assoc Kerala, 18(1): 88-92

Nasir A, Lanyon SR, Schares G, Anderson ML and Reichel MP, 2012. Sero-prevalence of Neospora caninum and Besnoitia besnoiti in South Australian beef and dairy cattle. Vet Parasitol, 186(3-4): 480-485, doi: 10.1016/j.vetpar. 2011.11 .032

Neverauskas CE, Nasir A and Reichel MP, 2015. Prevalence and distribution of Neospora caninum in water buffalo (Bubalus bubalis) and cattle in the Northern Territory of Australia. Parasitol Int, 64(5): 392-396, doi: 10.1016/ j.parint.2015.05.009 